\title{
Hubungan Kebiasaan Makan dan Status Gizi Terhadap Kejadian Apendisitis pada Anak di Yogyakarta
}

Hanum Atikasari, ${ }^{*}$ Susetyowati, *Akhmad Makhmudi**

*Departemen Kesehatn Gizi Fakultas Kedokteran Universitas Gadjah Mada

**Divisi Bedah Anak, Departemen Bedah Rumah Sakit Dr. Sardjito, Yogyakarta

Latar belakang. Apendisitis merupakan salah satu penyakit akut abdomen yang sering terjadi dan dilakukan operasi pada anak. Status gizi dan kebiasaan makan yang tidak baik menyebabkan penurunan respon imun dan peningkatan risiko infeksi pada anak.

Tujuan. Mengetahui hubungan kebiasaan makan dan status gizi dengan kejadian apendisitis pada anak di Yogyakarta.

Metode. Penelitian observasional dengan rancangan penelitian case control yang melibatkan 114 responden berusia 6-15 tahun yang dibagi menjadi dua kelompok. Kelompok kasus adalah pasien anak pasca operasi apendisitis di RS Khusus Anak 45, RSUP Dr. Sardjito, RS PKU Muhammadiyah Yogyakarta, dan RSKIA Bhakti Ibu, sedangkan kelompok kontrol adalah anak yang belum pernah menjalani operasi apendisitis dan bertempat tinggal satu wilayah dengan kelompok kasus.

Hasil. Kebiasaan makan menunjukkan hubungan bermakna terhadap kejadian apendisitis pada anak $p=0,001 \quad(O R=14,87$; IK95\%:3,28-67,43). Status gizi menunjukkan hubungan bermakna terhadap kejadian apendisitis pada anak $\mathrm{p}=0,042(\mathrm{OR}=2,60$; IK95\%:1,02-6,65).

Kesimpulan. Terdapat hubungan bermakna antara kebiasaan makan, kebiasaan jajan dan status gizi terhadap kejadian apendisitis pada anak di Yogyakarta. Sari Pediatri 2015;17(2):95-100.

Kata kunci : apendisitis, anak, status gizi, kebiasaan makan

\section{The Relationship of Eating Habits and Nutritional Status on the Incidence of Appendicitis in Children in Yogyakarta}

Hanum Atikasari, Susetyowati, Akhmad Makhmudi

Background. Appendicitis is the most common cause of acute abdominal pain requiring surgical intervention in children. Nutrition status and unhealthy eating habits also results in altered immune response and increase the risk of infection in children.

Objective. To determine the relationship of eating habits and nutritional status on the incidence of appendicitis in children in Yogyakarta

Method. This research was an observational research with a case-control study design involving 114 respondents aged 6-15 years, who were divided into two groups. The case group was postoperative appendicitis child patients at Rumah Sakit Khusus Anak Empat Lima, RSUP Dr. Sardjito, RS PKU Muhammadiyah Yogyakarta, and RSKIA Bhakti Ibu. The control group was children who had never undergone surgery for appendicitis and residing in the same area as the case group.

Result. Eating habits show a significant relationship on the incidence of appendicitis in children, $\mathrm{p}=0.000(\mathrm{OR}=14.87 ; 95 \% \mathrm{CI}=$ 3.28-67.43). Nutritional status shows a significant relationship on the occurrence of appendicitis in children; $\mathrm{p}=0.042(\mathrm{OR}=2.60$; $95 \% \mathrm{CI}=1.02-6.65)$.

Conclusion. There is a significant relationship between eating habits and nutritional status on the incidence of appendicitis in children in Yogyakarta. Sari Pediatri 2015;17(2):95-100.

Keywords : appendicitis, children, nutrition status, eating habits

Alamat korespondensi: Hanum Atikasari, S. Gz, Institusi: gizi kesehatan fakultas kedokteran UGM. Alamat: Jl. Farmako, Sekip Utara Yogyakarta 55281, Telp +62 274547 775, Fax: +62 2745547 775. Hp: 085643450999, E-mail: hanum76@gmail.com 
A pendisitis merupakan salah satu penyakit akut abdomen yang sering terjadi dan dilakukan operasi pada anak. ${ }^{1,2}$ Apendisitis dapat terjadi pada semua kelompok umur, tetapi insiden tertinggi terdapat pada anak usia belasan tahun dengan rata-rata rentang usia 6-10 tahun. ${ }^{3}$ Di Amerika Serikat, risiko apendisitis pada laki-laki lebih tinggi $(8,6 \%)$ dibanding perempuan $(6,7 \%){ }^{2}$ Apabila tidak segera ditangani, bahaya apendisitis dapat meningkatkan risiko kesakitan dan kematian. ${ }^{4}$

Peradangan pada apendiks diawali dengan obstruksi lumen. Hal ini yang mengakibatkan invasi di dinding apendiks oleh flora usus sehingga terjadi inflamasi dan infeksi. ${ }^{5}$ Penyebab terjadinya obstruksi, antara lain hiperplasia limfoid (60\%), apendikolit (33\%), benda asing (4\%), dan sebab lain seperti tumor dan parasit. ${ }^{6-8}$ Di sepanjang saluran cerna, termasuk apendiks, terdapat immunoglobulin sekretoar yang dihasilkan GALT (gut associated lymphoid tissue), yaitu Ig A. Immunoglobulin ini sangat efektif sebagai pelindung terhadap infeksi. ${ }^{7}$

Gizi merupakan salah satu faktor penentu penting dalam respon imunitas. Penelitian epidemiologi dan klinis menunjukkan bahwa kekurangan salah satu zat gizi dapat menghambat respons imunitas dan meningkatkan risiko infeksi. ${ }^{9}$ Penelitian ini bertujuan untuk mengetahui hubungan kebiasaan makan dan status gizi dengan kejadian apendisitis pada anak di Yogyakarta.

\section{Metode}

Penelitian observasional dengan rancangan penelitian case control. Rancangan case control yang digunakan adalah matched case controlstudy dengan perbandingan $1: 1$. Subjek dibagi ke dalam dua kelompok yaitu kelompok kasus dan kelompok kontrol, satu kasus dipasangkan dengan kontrol yang sesuai dengan umur, jenis kelamin, dan wilayah tinggal.

Penelitian dilaksanakan di Yogyakarta pada bulan April-Juni 2014 dengan lokasi pengambilan kasus di rumah sakit Khusus Anak 45, RSUP Dr. Sardjito, RS PKU Muhammadiyah Yogyakarta, dan RSKIA Bhakti Ibu. Penelitian ini melibatkan 114 responden berusia 6-15 tahun yang dibagi menjadi dua kelompok dengan jumlah yang sama. Kriteria kelompok kasus, yaitu pasien anak pasca operasi apendisitis dengan rentang waktu maksimal 3 bulan sebelum pengambilan data, berdomisili di wilayah Yogyakarta, memiliki catatan medik yang lengkap, serta tidak ditemukan diagnosis lain. Kriteria pada kelompok kontrol, yaitu belum pernah didiagnosis apendisitis, jenis kelamin sama dan tempat tinggal berdekatan dengan kelompok kasus, dan usia anak sama atau berjarak maksimal satu tahun di atas atau di bawah kelompok kasus.

Data karakteristik responden kelompok kasus diperolah dari rekam medik, meliputi nama, usia, jenis kelamin, diagnosis medis, waktu operasi, alamat, nama orang tua, dan pekerjaan orang tua. Data kebiasaan makan diperoleh melalui wawancara menggunakan kuesioner kebiasaan makan yang terdiri atas 6 pertanyaan, meliputi frekuensi makan sehari-hari, menu makanan, kebiasaan mengonsumsi sayur, air minum, fast food, dan mie instan. Setiap pertanyaan memiliki skor tertinggi 2 dan skor terendah 1. Dikategorikan baik apabila skor $>+1$ SD, dan dikategorikan kurang apabila skor $\leq+1$ SD. Data status gizi diperoleh dengan hasil pengukuran berat badan dan tinggi badan pre operasi dan pengukuran berat badan dan tinggi badan pada kelompok kontrol secara langsung. Status gizi dibedakan menjadi 2 kategori yaitu normal/ lebih ( $>2$ $\mathrm{SD})$ dan kurang ( $\leq 2 \mathrm{SD})$.

\section{Hasil}

Subjek penelitian 114 anak, terdiri atas 57 anak dengan apendisitis dan 57 anak sebagai kontrol. Jenis kelamin dan usia anak pada kelompok kasus dilakukan matching sehingga jumlah anak kedua kelompok sama. Jumlah anak perempuan lebih banyak dibandingkan laki-laki, yaitu $31(54,4 \%)$ berbanding $26(45,6 \%)$ orang. Kategori usia anak 6-12 tahun lebih banyak dengan jumlah $42(73,7 \%)$ orang jika dibandingkan dengan kategori usia $>12-15$ tahun $(26,3 \%)$. Tingkat pendidikan anak rata-rata pada tingkat $\mathrm{SD}$, yaitu 37 $(64,9 \%)$ pada kelompok kasus dan 39 orang pada kelompok kontrol $(68,4 \%)$.

Sebagian besar anak pada kedua kelompok memiliki status gizi normal, $35(61,4 \%)$ pada kelompok anak dengan apendisitis dan $37(64,9 \%)$ pada kelompok anak tidak apendisitis. Ditemukan status gizi kurus lebih banyak pada kelompok anak apendisitis, yaitu 14 $(24,6 \%)$ berbanding 8 (14\%) orang. Perbedaan kedua kelompok juga terlihat dari jumlah anak yang sangat kurus. Pada kelompok apendisitis terdapat 3 (5,3\%) orang, sedangkan pada kelompok tidak apendisitis tidak ditemukan anak status gizi sangat kurus. 
Tabel 1. Karakteristik subjek penelitian

\begin{tabular}{|c|c|c|c|c|}
\hline \multirow[t]{2}{*}{ Variabel } & \multicolumn{2}{|c|}{ Kasus } & \multicolumn{2}{|c|}{ Kontrol } \\
\hline & $\mathrm{n}$ & $\%$ & $\mathrm{n}$ & $\%$ \\
\hline \multicolumn{5}{|l|}{ Jenis kelamin } \\
\hline Laki-laki & 26 & 45,6 & 26 & 45,6 \\
\hline Perempuan & 31 & 54,4 & 31 & 54,4 \\
\hline \multicolumn{5}{|c|}{ Umur anak (tahun) } \\
\hline $6-12$ & 42 & 73,7 & 42 & 73,7 \\
\hline$>12-15$ & 15 & 26,3 & 15 & 26,3 \\
\hline \multicolumn{5}{|l|}{ Pendidikan } \\
\hline TK & 6 & 10,5 & 4 & 7,0 \\
\hline SD & 37 & 64,9 & 39 & 68,4 \\
\hline SMP & 14 & 24,6 & 14 & 24,6 \\
\hline \multicolumn{5}{|l|}{ Status gizi } \\
\hline Obes & 4 & 7,0 & 7 & 12,3 \\
\hline Overweight & 1 & 1,8 & 5 & 8,8 \\
\hline Normal & 35 & 61,4 & 37 & 64,9 \\
\hline Kurus & 14 & 24,6 & 8 & 14,0 \\
\hline Sangat kurus & 3 & 5,3 & 0 & 0 \\
\hline Jumlah & 57 & 100 & 57 & 100 \\
\hline
\end{tabular}

Tabel 2. Kebiasaan makan subjek penelitian

\begin{tabular}{|c|c|c|c|c|}
\hline \multirow{2}{*}{ Kebiasaan makan } & \multicolumn{2}{|c|}{ Kasus } & \multicolumn{2}{|c|}{ Kontrol } \\
\hline & $\mathrm{n}$ & $\%$ & $\mathrm{~N}$ & $\%$ \\
\hline \multicolumn{5}{|l|}{ Frekuensi makan (x/ hari) } \\
\hline$<3$ & 25 & 43,9 & 6 & 10,5 \\
\hline$\geq 3$ & 32 & 56,1 & 51 & 89,5 \\
\hline \multicolumn{5}{|l|}{ Menu makan sehari-hari } \\
\hline Makanan pokok+lauk/ sayur saja & 53 & 93,0 & 38 & 66,7 \\
\hline Makanan pokok+ lauk +sayur/buah & 4 & 7,0 & 19 & 33,3 \\
\hline \multicolumn{5}{|l|}{ Konsumsi air minum } \\
\hline$<\mathrm{AKG}$ & 48 & 84,2 & 24 & 42,1 \\
\hline$\geq \mathrm{AKG}$ & 9 & 15,8 & 33 & 57,9 \\
\hline \multicolumn{5}{|l|}{ Konsumsi sayur (/ minggu) } \\
\hline$<7 \mathrm{x}$ & 45 & 78,9 & 24 & 42,1 \\
\hline$\geq 7 x$ & 12 & 21,1 & 33 & 39,5 \\
\hline \multicolumn{5}{|l|}{ Konsumsi fast food (/ bulan) } \\
\hline$\geq 4 x$ & 28 & 49,1 & 18 & 31,6 \\
\hline$<4 \mathrm{x}$ & 29 & 50,9 & 39 & 68,4 \\
\hline \multicolumn{5}{|l|}{ Konsumsi mie instan (/ bulan) } \\
\hline$\geq 4 x$ & 53 & 93,0 & 32 & 56,1 \\
\hline$<4 \mathrm{x}$ & 4 & 7 & 25 & 43,9 \\
\hline Jumlah & 57 & 100 & 57 & 100 \\
\hline
\end{tabular}

Keterangan: AKG angka kecukupan gizi

Sari Pediatri, Vol. 17, No. 2, Agustus 2015 
Tabel 3. Hubungan status gizi dengan kejadian apendisitis

\begin{tabular}{|c|c|c|c|c|c|c|c|c|c|}
\hline \multirow[t]{2}{*}{ Status gizi } & \multicolumn{2}{|c|}{ Apendisitis } & \multicolumn{2}{|c|}{ Tidak kontrol } & \multicolumn{2}{|c|}{ Total } & \multirow[t]{2}{*}{ OR } & \multirow[t]{2}{*}{ IK95\% } & \multirow[t]{2}{*}{$\mathrm{p}$} \\
\hline & $\mathrm{n}$ & $\%$ & $\mathrm{~N}$ & $\%$ & $\mathrm{n}$ & $\%$ & & & \\
\hline Kurang & 17 & 29,8 & 8 & 14,0 & 25 & 21,9 & 2,60 & $1,02-6,65$ & $0,042^{*}$ \\
\hline Normal/ lebih & 40 & 70,2 & 49 & 86,0 & 89 & 78,1 & & & \\
\hline Total & 57 & 100 & 57 & 100 & 114 & 100 & & & \\
\hline
\end{tabular}

${ }^{*}$ chi-square test

Tabel 4. Hubungan kebiasaan makan dengan kejadian apendisitis

\begin{tabular}{|c|c|c|c|c|c|c|c|c|c|}
\hline \multirow{2}{*}{ Kebiasaan makan } & \multicolumn{2}{|c|}{ Apendisitis } & \multicolumn{2}{|c|}{ Tidak kontrol } & \multicolumn{2}{|c|}{ Total } & \multirow[t]{2}{*}{ OR } & \multirow[t]{2}{*}{ IK95\% } & \multirow[t]{2}{*}{$\mathrm{p}$} \\
\hline & $\mathrm{n}$ & $\%$ & $\mathrm{~N}$ & $\%$ & $\mathrm{n}$ & $\%$ & & & \\
\hline Kurang baik & 55 & 96,5 & 37 & 64,9 & 92 & 80,7 & 14,87 & $3,28-67,43$ & $0,001^{*}$ \\
\hline Baik & 2 & 3,5 & 20 & 35,1 & 22 & 19,3 & & & \\
\hline Total & 57 & 100 & 57 & 100 & 114 & 100 & & & \\
\hline
\end{tabular}

Karakteristik kebiasaan makan dinilai dari frekuensi makan, menu makan sehari-hari, konsumsi air minum, frekuensi konsumsi sayur, fast food, dan mie instan. Berdasarkan Tabel 3 diketahui bahwa frekuensi makan $<3 \mathrm{x} /$ hari lebih banyak ditemukan pada anak apendisitis dibandingkan tidak apendisitis, $25(43,9 \%)$ berbanding $6(10,5 \%)$.

Anak dengan apendisitis cenderung mengonsumsi menu sehari-hari berupa makanan pokok+lauk/ sayur saja. Apabila dibandingkan dengan anak tidak apendisitis, jumlah anak yang makan dengan menu tersebut $53(93,0 \%)$ orang, sedangkan pada anak tidak apendisitis $38(66,7 \%)$. Konsumsi air minum pada anak apendisitis yang kurang dari angka kecukupan gizi (AKG) berdasarkan umur lebih banyak dibandingkan anak tidak apendisitis. Jumlah anak pada kelompok apendisitis $48(84,2 \%)$ orang, sedangkan pada kelompok tidak apendisitis 24 (42,1\%).

Anak dengan apendisitis cenderung jarang mengonsumsi sayuran apabila dibandingkan anak tidak apendisitis. Jumlah anak yang jarang mengonsumsi sayur $(<7 \mathrm{x} /$ minggu $) 45(78,9 \%)$ pada anak apendisitis dan 24 $(42,1 \%)$ tidak apendisitis. Kebiasaan mengonsumsi fast food $\geq 4 \mathrm{x} /$ bulan lebih banyak terdapat pada kelompok anak apendisitis dibandingkan tidak apendisitis, 28 $(49,1 \%)$ berbanding $18(31,6 \%)$. Selain itu, anak apendisitis umumnya lebih sering mengonsumsi mie instan ( $\geq 4 \mathrm{x} /$ bulan). Jumlah anak apendisitis dan tidak apendisitis yang sering mengonsumsi mie instan, 53 (93,0\%) berbanding 32 orang $(56,1 \%)$.

Status gizi kurang, banyak ditemukan pada anak dengan apendisitis dibandingkan tidak apendisitis, $17(29,8 \%)$ berbanding $8(14,0 \%)$. Anak dengan status gizi normal dan lebih, banyak ditemukan pada anak tidak apendisitis dibandingkan anak apendisitis, $86 \%$ berbanding 70,2\%. Hasil analisis uji chi-square menunjukkan terdapat hubungan antara status gizi dengan kejadian apendisitis $(\mathrm{p}<0,05)$. Status gizi memiliki nilai OR: 2,60 (IK95\%:1,02-6,65) yang berarti anak dengan status gizi kurang akan mengalami apendisitis 2,6 kali lebih besar dibandingkan anak dengan status gizi normal dan lebih.

Analisis bivariat mengategorikan kebiasaan makan menjadi baik dan kurang. Aspek yang dilihat adalah frekuensi makan, menu makanan sehari-hari, konsumsi air minum, frekuensi konsumsi sayur, fast food, dan mie instan. Hasil analisis uji chi-square menunjukkan terdapat hubungan antara kebiasaan makan dengan kejadian apendisitis $(\mathrm{p}<0,05)$. Kebiasaan makan memiliki nilai OR: 14,87 (IK95\%: 3,28-67,43) yang berarti anak dengan kebiasaan makan kurang baik akan mengalami apendisitis 14,87 kali lebih besar dibandingkan anak dengan kebiasaan makan baik.

\section{Pembahasan}

Kejadian yang mengawali terjadinya apendisitis adalah infeksi yang memicu hiperplasia limfoid pada dinding apendiks yang membuat obstruksi pada lumen proksimal. ${ }^{10}$ Asupan makan yang tidak adekuat menyebabkan penurunan berat badan, imunitas 
menurun, kerusakan jaringan mukosa, invasi patogen, serta gangguan pertumbuhan dan perkembangan pada anak. ${ }^{11}$

Pada penelitian ini, kebiasaan makan memiliki hubungan yang bermakna terhadap kejadian apendisitis. Anak dengan kebiasaan makan yang kurang baik lebih berisiko terkena apendisitis dibandingkan anak dengan kebiasaan makan baik. Kebiasaan makan meliputi frekuensi makan, pemilihan menu sehari-hari, konsumsi air minum, konsumsi sayur, konsumsi fast food, dan mie instan. Penelitian sebelumnya yang dilakukan di Inggris menyebutkan asupan nutrisi (karbohidrat, protein, lemak, vitamin, mineral, dan air), pada kelompok anak dengan apendisitis lebih rendah dibandingkan tidak apendisitis. ${ }^{10}$

Konsumsi fast food meningkatkan asupan kalori, lemak, lemak jenuh, natrium, dan minumam ringan serta menurunkan asupan vitamin $\mathrm{A}$, vitamin $\mathrm{C}$, susu, buah-buahan, dan sayuran dibandingkan orang yang tidak makan cepat saji. ${ }^{12}$ Penelitian Park dkk ${ }^{13}$ yang dilakukan di Korea menyatakan pada kelompok orang yang sering mengonsumsi mie instan, asupan energi, lemak, natrium, tiamin, dan riboflavin lebih tinggi dibandingkan yang tidak mengonsumsi mie instan. Sebaliknya, asupan protein, kalsium, fosfor, besi, kalium, vitamin $\mathrm{A}$, niasin, dan vitamin $\mathrm{C}$ secara signifikan lebih rendah. Selain itu, mengonsumsi sayur dan buah juga lebih rendah pada kelompok tersebut. Dapat dikatakan bahwa mengonsumsi fast food dan mie instan berkontribusi pada peningkatan asupan energi, tetapi rendah dalam asupan mikronutrien. Asupan vitamin dan mineral yang tidak adekuat dapat memicu penurunan imunitas yang cenderung mengarah pada kejadian infeksi. ${ }^{14}$

Penelitian kami juga menunjukkan bahwa terdapat hubungan antara status gizi terhadap kejadian apendisitis. Malnutrisi dan infeksi memiliki hubungan yang sangat erat karena gizi yang buruk menyebabkan anak menjadi kurus, lemah, dan rentan terhadap infeksi, terutama karena integritas struktural dan fungsional jaringan epitel dan inflamasi. ${ }^{15}$

Penelitian kasus kontrol yang dilakukan Nelson $\mathrm{dkk}^{16}$ di Southampton, Inggris, pada 53 anak apendisitis dan 97 anak sebagai kontrol dengan usia 13-15 tahun menunjukkan rata-rata berat badan anak pada kelompok anak apendisitis lebih rendah dibandingkan tidak apendisitis. Rata-rata berat badan anak apendisitis pada penelitian tersebut adalah $51 \mathrm{~kg}$, sedangkan kontrol 54,9 kg. Selain itu, rata-rata tinggi badan anak dengan apendisitis juga menunjukkan hasil dalam batas signifikan. Rata-rata tinggi badan kelompok kasus lebih pendek (1,61 m) dibanding kelompok kontrol (1,64 m).

Penelitian Bekele dkk, ${ }^{17}$ yang dilakukan pada 147 anak dengan usia di bawah 13 tahun di Etiopia, juga menunjukkan bahwa lebih dari seperempat anak dengan kasus apendisitis mengalami underweight dan stunted.

\section{Kesimpulan}

Hasil penelitian ini menunjukkan bahwa terdapat hubungan antara kebiasaan makan, dan status gizi terhadap kejadian apendisitis pada anak di Yogyakarta. Sebaiknya, orangtua mulai membiasakan makan yang baik sejak dini dan memperhatikan status gizi anak. Diperlukan adanya peran aktif orang tua dalam mengawasi dan mengarahkan pemilihan makanan pada anak. Perlu dilakukan penelitian lanjutan untuk analisis lebih mendalam mengenai asupan mikronutrien terhadap kejadian apendisitis pada anak.

\section{Daftar pustaka}

1. Reynolds S, Jaffe D. Diagnosing abdominal pain in a pediatric emergency department. Pediatr Emerg Care 1992;8:126-8.

2. Addiss DG, Shaffer N, Fowler BS, Tauxe R V. The epidemiology of appendicitis and appendictomy in the United Stated. Am J Epidemiol 1990;132:910-25.

3. Raffensperger JG. Swenson's Pediatric Surgery. Raffensperger JG, penyunting. Edisi ke-5. New York: AppletonCentury-Crofts; 1990.h.843.

4. Rothrock SG, Rothrock SG, Pagane J, Pagane J. Acute appendicitis in children: Emergency Department Diagnosis and Management. Ann Emerg Med 2000;36: 39-51.

5. Andersen BR, Kallehave FL, Andersen HK. Antibiotics versus placebo for prevention of postoperative infection after appendicectomy. Cochrane Database Syst Rev 2005;3:CD001439.

6. Weissleder R, Wittenberg J, Harisinghani M, penyunting. Primer of diagnostic imaging. St. Louis: Mosby Inc; 2007.

7. Sjamsuhidajat R. Buku ajar ilmu bedah Sjamsuhidajatde Jong. Sjamsuhidajat R, Karnadihardja W, Prasetyono 
TOH, Rudiman R, penyunting. Edisi ke-3. Jakarta: Penerbit Buku Kedokteran EGC; 2007.

8. Birnbaum B, Wilson S. Appendicitis at the millennium. Radiology 2000;215:337-48.

9. Chandra, R K.. Nutrition and the immune system: an introduction. Am J Clin Nutr 1997; 66,460-3.

10. Barker DJP, Morris J, Nelson M. Vegetable consumption and acute appendicitis in 59 England and Wales. Br Med J 1986;292:927-30.

11. Müller O, Garenne M, Kouyaté B, Becher H. The association between protein-energy malnutrition, malaria morbidity and all-cause mortality in West African children. Trop Med Int Heal 2003;8:507-11.

12. Paeratakul S, Ferdinand DP, Champagne CM, Ryan DH, Bray G a. Fast-food consumption among US adults and children: Dietary and nutrient intake profile. J Am Diet Assoc 2003;103:1332-8.
13. Park J, Lee JS, Jang YA, Chung HR, Kim J. A comparison of food and nutrient intake between instant noodle consumers and non-instant noodle consumers in Korean adults. Nutr Res Pract 2011;5:443-9.

14. Maggini S, Wintergerst ES, Beveridge S, Hornig DH. Selected vitamins and trace elements support immune function by strengthening epithelial barriers and cellular and humoral immune responses. Br J Nutr 2007;98 Suppl 1:S29-S35.

15. Katona P, Katona-apte J. The Interaction between Nutrition and Infection. Clin Infect Dis 2008;46:1582-8.

16. Nelson M, Morris J, Barker DJ, Simmonds S. A casecontrol study of acute appendicitis and diet in children. J Epidemiol Community Health 1986;40:316-8.

17. Bekele A, Mekasha A. Clinical profile and risk factors for perforation of acute appendicitis in children. East Afr Med J 2006;83:434-9. 